\title{
Characteristics, Properties and Analytical Methods of Cefquinome - A Review
}

\author{
SHAZA W. SHANTIER \\ Department of Pharmaceutical Chemistry, \\ Faculty of Pharmacy, University of Khartoum, P.O.Box-1996, Sudan \\ sshantier@yahoo.com
}

Received 30 November 2018 / Accepted 30 December 2018

\begin{abstract}
Drugs have been used for the treatment of infectious diseases since the $17^{\text {th }}$ century. However, chemotherapy as a science began in the first decade of the $20^{\text {th }}$ century with understanding of the principles of selective toxicity, the specific chemical relationships between microbial pathogens and drugs, the development of drug resistance and the role of combined therapy. Analysis of such drugs, whether used for treatment of human or animal illness, is essential in understanding the bioavailability and therapeutic control which will ensure their activity and safety. Thus, this review aims to highlight the characteristics, specifically the pharmacokinetic parameters and the analytical methods reported in literature for cefquinome, a fourth generation cephalosporine used to treat infections caused by gram-positive and gram-negative microorganisms.
\end{abstract}

Keywords: Infection, Antibiotics, Activity, Cefquinome, Cephalosporines

\section{Introduction}

Antibiotics are type of antimicrobial drugs used in the treatment and prevention of bacterial infections ${ }^{1}$. Generally, they are chemical substances derived from, or produced by living organisms, as well as their structural analogs obtained by synthesis, capable of inhibiting in low concentration, the growth and even destruction of other microrganisms ${ }^{2}$.

Antibiotics are commonly classified based on their mechanism of action, chemical structure, or spectrum of activity. An ideal antibiotic exhibits selective toxicity by targeting bacterial functions or growth processes for example cell wall synthesis (penicillins and cephalosporins), the cell membrane (polymyxins) and essential bacterial enzymes (rifamycins, lipiarmycins, quinolones and sulfonamides) ${ }^{3}$.

For more than 40 years, antibiotics approved by the FDA have been used to treat, control and prevent diseases in animals as well as in humans. The benefits of using antibiotics to treat and prevent animal disease extend far beyond the farm. In fact, research has shown that as rates of animal illnesses increase, so do rates of human illness ${ }^{4}$. At least one study has shown that even a slight increase in animal-illness rate leads to a greater human-illness rate than the development of antibiotic resistance ${ }^{5}$. 
Antibiotic resistance is a phenomenon that occurs following extensive contact of bacteria with antibiotics and their presence in the environment. It is one of the biggest threats to global health, food security and development today. New resistance mechanisms are emerging and spreading globally, threatening our ability to treat common infectious diseases. A growing list of infections such as pneumonia, tuberculosis, blood poisoning and gonorrhoea are becoming harder and sometimes impossible, to treat as antibiotics become less effective.

A global action plan on antimicrobial resistance, including antibiotic resistance, was endorsed at the World Health Assembly in May 2015 and supported by the governing bodies of FAO (Food and Agriculture Organization of the United Nations) and OIE (World Organization for Animal Health). The global action plan aims to ensure prevention and treatment of infectious diseases with safe and effective medicines.

Faced by the high levels of antibiotic resistance as well as the reduction of the approved drugs by FDA in recent years and the potential allergenic reactions that they may illicit in certain individuals, it is absolutely necessary to develop new drugs, adopt new therapeutic strategies and incorporate cultural changes ${ }^{6-8}$.

Nevertheless, severe quality control of all pharmaceutical formulations is required to ensure their safety standards and efficacy ${ }^{9}$.

Thus, the physicochemical characteristics of drugs must conform to the standards necessary for the proper handling and industrialization of the same drug to ensure the confidence at treatments about their function ${ }^{10}$.

Based on those information and facts that point to the importance of the development of analytical methods; characteristics, physiochemical properties and reported methods already developed for the quantification and identification of cefquinome, a fourth generation cephalosporin among the second largest class of $\beta$-lactam antibiotics, will be highlighted in this review.

\section{Cephalosporines}

Cephalosporines are broad spectrum, $\beta$-lactam antibacterial agents which inhibit bacterial cell wall synthesis. They were discovered from a fungal colony in Sardinian sewer water in $1948^{11}$.

The discovery of cephalosporines nucleus, 7-aminocephalosporanic acid (Figure 1), promoted the semi-synthetics of cephalosporin of medicinal value. Modifications of the basic 7-ACA nucleus have resulted from acylations of the 7-amino group with different acids or nucleophilic substitution or reduction of the acetoxyl group. This yielded drugs of good therapeutic activity, low toxicity, acid stability and decreased allergenicity. They can be classified into four major groups or generations, depending mainly on the spectrum of antimicrobial activity. As a general rule, first-generation compounds have better activity against gram-positive organisms and the latter compounds (fourth generation) exhibit improved activity against gram-negative aerobic organisms ${ }^{12}$.<smiles>CC(=O)OCC1=C(C(=O)O)N2C(=O)[C@@H](N)[C@H]2SC1</smiles>

Figure 1. Chemical structure of 7-aminocephalosporanic acid 


\section{Cefquinome}

Among the fourth generation, cefquinome (Figure 2) is a semisynthetic, broad spectrum aminothiazolyl cephalosporin. In 1993, cefquinome was approved for the first time as broad spectrum antibacterial drug.<smiles>CON=C(C(=O)NC1C(=O)N2C(C(=O)O)=C(Cc3cccc4c3CCCC4)CS[C@H]12)c1csc(N)n1</smiles>

Figure 2. Chemical structure of cefquinome sulphate

It is formulated as ready to use suspension for injection. It is marketed under different brand names: Cobactan ${ }^{\circledR} 2.5 \%$ (Intervent, Austria and Germany); Cefquinor LC ${ }^{\circledR}$ (Bayer, Germany); Cefimam ${ }^{\circledR}$ (Norbrook Laboratories, Ireland); Mastivia ${ }^{\circledR}$ (Fatro, Italy); Virbactan ${ }^{\circledR}$ (Vibrac, Belguim, Germany) $^{13}$.

\section{Physicochemical properties}

Cefquinome is chemically designated as (6R,7R)-7-[[(2Z)-2-(2-amino-1,3-thiazol-4-yl)-2methoxyiminoacetyl]amino]-8-oxo-3-(5,6,7,8-tetrahydroquinolin-1-ium-1-ylmethyl)-5-thia1-azabicyclo[4.2.0]oct-2-ene-2-carboxylate. Its chemical formula is $\mathrm{C}_{23} \mathrm{H}_{26} \mathrm{~N}_{6} \mathrm{O}_{5} \mathrm{~S}_{2}$, has molecular weight of $528.602 \mathrm{~g} / \mathrm{mol}$. It is white powder, freely soluble in water; with $\log \mathrm{P}$ value $^{14}$ of -1.49 .

\section{Synthesis}

As a kind of new animal appropriation antibiotics, there were fewer reports about the synthesis of its analogues and intermediates and the first synthesized patent was in 1984. Up to now, the reported synthesis methods were mainly used the 7-ACA or cefotaxime as the raw material (Scheme 1). Cefquinome is synthesized by the structural modification of cefotaxime (1). Cefotaxime acid is converted to silyl ester (2) by derivatization with $N$-methyl- $N$-(trimethylsilyl) trifluoroacetamide (MSTFA). Treatment of this intermediate with trimethylsilyl iodide gives the allylic iodide (3). Displacement of the halogen moiety and hydrolysis of the silyl ester followed by adjustments of the $\mathrm{pH}$ leads to the betaine cefquinome $(4)^{15}$.

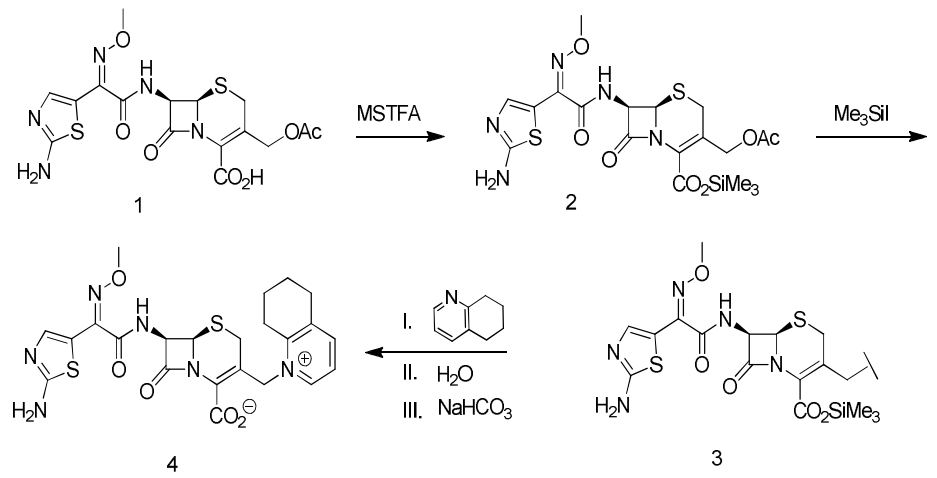

Scheme 1. Chemical synthesis of cefquinome 


\section{Mechanism of action}

Cefquinome binds to and inactivates penicillin-binding proteins (PBPs) located on the inner membrane of the bacterial cell wall. PBPs are enzymes involved in the terminal stages of assembling the bacterial cell wall and in reshaping the cell wall during growth and division. Inactivation of PBPs interferes with the cross-linkage of peptidoglycan chains necessary for bacterial cell wall strength and rigidity. This results in the weakening of the bacterial cell wall and causes cell lysis ${ }^{16}$.

\section{Pharmacokinetics and pharmacodynamics}

Chemically, its zwitterionic structure facilitates rapid penetration across biological membranes, including porins of bacterial cell walls. It has high affinity to target penicillinbinding proteins. The $\beta$-lactam nucleus is responsible for its reactivity; a quaternary quinolinium, an aminothiazolyl moiety and an unusual $O$-alkylated oxime are the main peripheral functional groups. It has a relatively short half-life of about 2.5 hours. It is less than $5 \%$ protein bound and is excreted unchanged in the urine ${ }^{17}$.

\section{Resistance and clinical uses}

Microorganisms may exhibit resistance to drugs by different mechanisms including production of enzymes that destroy drugs, altering their metabolic pathway, changing permeability or developing an altered structural target to the $\operatorname{drug}^{18}$.

Cefquinome is highly resistant against inactivation by $\beta$-lactamase producing bacteria which explains its broad spectrum activity. Its pharmacological and antibacterial properties are valuable in the treatment of infections caused by various types of gram positive and Gram negative bacteria, such as Actinobacillus spp., Haemophilus spp., Pasteurella spp., E. coli, Staphylococcus spp., Streptococcus spp., Salmonella spp., Clostridium spp., Corynebacterium and Erysipelothrix rhusiopathiae.

\section{Veterinary use}

It is used for the treatment of bovine respiratory disease (BRD) ${ }^{19}$ in cattle, respiratory tract infections in pigs, dermatitis and infectious ulbar necrosis and also used for other illnesses, such as "shipping fever", a pneumonia-like illness commonly found in cattle.

\section{Methods of analysis}

Drug analysis plays an important role in the pharmaceutical field ${ }^{20,21}$. Analytical techniques are extremely important to conduct bioavailability and bioequivalence studies, quantification and identification of the drug substance and impurities and physical and chemical stability. Furthermore pharmacokinetic parameters for the therapeutic monitoring of the drug are also assessed using bioanalytical techniques ${ }^{22,23}$.

The analytical methods described in the literature for the determination of cefquinome are shown in Table 1 and 2. Those methods can be categorized depending on the method of analysis and the matrix analysed into chromatographic, spectrophotometric and microbiological methods of analysis.

As can be seen in Table 1, there is a predominance of pharmacokinetics determination in animals' biological fluids such as plasma, urine and serum, using high-performance liquid chromatography (HPLC). The chromatographic separation was carried out applying high performance or ultra high performance techniques with iscocratic or gradient elution. Methanol, acetonitrile, water and buffer were mainly used as eluents in the reported methods. 
Table 1. HPLC and spectroscopic-based methods for the determination of cefquinome

\begin{tabular}{|c|c|c|c|c|c|}
\hline Method & Matrices & Column and flow rate & Mobile phase & Detection & Reference \\
\hline UHPLC & Bovine milk & $\begin{array}{l}\mathrm{C}_{18} ; 0.30 \mathrm{~mL} / \mathrm{min} . \\
\text { The injection volume was } \\
10 \mu \mathrm{L}\end{array}$ & $\begin{array}{l}\text { Mobile phase: Solvent A ( } 0.1 \% \text { formic } \\
\text { acid in water) and solvent B (methanol). } \\
\text { Initial gradient conditions were set to 5\% } \\
\text { B before incorporating a linear gradient } \\
\text { increasing to 55\% }\end{array}$ & ESI-MS & [41] \\
\hline HPLC & Plasma & $\mathrm{C}_{18} ; 0.9 \mathrm{~mL} / \mathrm{min}$ & $\begin{array}{c}\text { Linear gradient of acetonitrile in water } \\
\text { with a constant } 0.1 \% \text { trifluoroacetic } \\
\text { acid solution. }\end{array}$ & UVat $268 \mathrm{~nm}$ & [42] \\
\hline HPLC & Plasma & $\mathrm{C}_{18} ; 1 \mathrm{~mL} / \mathrm{min}$ & $\begin{array}{l}\text { Mobile phase: mixture of } \\
\text { ACN/phosphate buffer }(0.085 \mathrm{M}, \mathrm{pH} \\
2.8) \text { at a ratio of } 85: 15(\mathrm{v} / \mathrm{v}) \text {. }\end{array}$ & $\mathrm{UV}$ at $265 \mathrm{~nm}$ & [43] \\
\hline HPLC & API & $\mathrm{C}_{18} ; 1 \mathrm{~mL} / \mathrm{min}$ & $\begin{array}{l}\text { Mobile phase: ammonium acetate } \\
\text { buffer: acetonitrile }(80: 20 \mathrm{v} / \mathrm{v}) \text {. }\end{array}$ & $\mathrm{UV}$ at $268 \mathrm{~nm}$ & [39] \\
\hline LC & $\begin{array}{l}\text { Water and } \\
\text { meat }\end{array}$ & $\begin{array}{l}\mathrm{C} 18(150 \mathrm{~mm} \times 0.3 \mathrm{~mm} \\
5 \mu \mathrm{m}, 100 \AA), 20 \mu \mathrm{L} / \mathrm{min}\end{array}$ & $\begin{array}{c}\text { Gradient program combining solvent } \mathrm{A} \\
(0.1 \% \text { formic acid in water, } \mathrm{pH} 4) \text { and } \\
\text { solvent } \mathrm{B} \text { (acetonitrile-methanol } \\
(50: 50, \mathrm{v} / \mathrm{v})\end{array}$ & $\mathrm{UV}$ at $250 \mathrm{~nm}$ & [44] \\
\hline HPLC & API & $\begin{array}{l}\text { LiChroCART RP-18 column } \\
(5 \mu \mathrm{m} \text { particle size, } 125 \mathrm{~mm} \times \\
4 \mathrm{~mm}), 1 \mathrm{~mL} / \mathrm{min} .\end{array}$ & $\begin{array}{l}\text { Mobile phase consisted of } 10 \text { volumes } \\
\text { of acetonitrile and } 90 \text { volumes of an } \\
0.02 \mathrm{M} \text { phosphate buffer ( } \mathrm{pH} 7.0) \text {. }\end{array}$ & $\mathrm{UV}$ at $268 \mathrm{~nm}$ & [40] \\
\hline LC & $\begin{array}{l}\text { Neutropenic } \\
\text { mouse thigh }\end{array}$ & $\begin{array}{l}\mathbf{C}_{18}(2.1 \mathrm{~mm} \times 50 \mathrm{~mm} \text {, } \\
3.5 \mu \mathrm{m}) \text { The iniection } \\
\text { volume was } 5 \mu \mathrm{L} \text { with a } \\
\text { flow rate of } 250 \mu \mathrm{L} / \mathrm{min}\end{array}$ & $\begin{array}{l}\text { Mobile phase: acetonitrile and } 5 \mathrm{mM} \\
\text { ammonium acetate containing } 0.1 \% \\
\text { formic acid (10:90, v/v) provided as an } \\
\text { isocratic elution }\end{array}$ & MS/MS & [45] \\
\hline UHPLC & bovine muscle & $\mathrm{C}_{18} ; 1 \mathrm{~mL} / \mathrm{min}$ & $\begin{array}{l}\text { Binary gradient separation comprising } \\
\text { of } 0.01 \% \text { formic acid and } 0.2 \mathrm{mM} \\
\text { ammonium acetate in water (mobile } \\
\text { phase } \mathrm{A} \text { ) and } 0.01 \% \text { formic acid in } \\
\text { acetonitrile (mobile phase } \mathrm{B}) \text {. }\end{array}$ & ESI-MS/MS & [46] \\
\hline HPLC & $\begin{array}{l}\text { Pig urine and } \\
\text { muscle }\end{array}$ & $\begin{array}{l}\text { column }(150 \times 2.0 \mathrm{~mm}, 4 \mu \mathrm{m}), \\
\text { with a C18 guard column } \\
(4 \times 3.0 \mathrm{~mm}), \\
2 \mu \mathrm{L} / \mathrm{min} . \text { Injection vol. } 10 \mu \mathrm{L}\end{array}$ & $\begin{array}{l}\text { Mobile phase: a binary mixture of } \\
\text { solvents A }(0.1 \% \text { aqueous formic acid) } \\
\text { and B (MeOH). }\end{array}$ & MS/MS & [47] \\
\hline
\end{tabular}




\begin{tabular}{|c|c|c|c|c|c|}
\hline UHPLC & cow milk & $\begin{array}{l}\mathrm{C}_{18}(150 \mathrm{~mm} \mathrm{~L} \times 1.0 \mathrm{~mm} \\
\mathrm{ID}) \text { with } 1.7 \mu \mathrm{m} \text { particle } \\
\text { size, } 0.125 \mathrm{~mL} / \mathrm{min}\end{array}$ & $\begin{array}{l}\text { Isocratic elution of mobile phase } \\
\text { (water-acetonitrile-formic acid, } 74.9 \text { : } \\
25.0: 0.1 \mathrm{v} / \mathrm{v} / \mathrm{v} \text { ) }\end{array}$ & MS/MS & {$[48]$} \\
\hline LC & Mouse thigh & $\begin{array}{l}\mathbf{C}_{18}(2.1 \mathrm{~mm} \times 50 \mathrm{~mm} \\
3.5 \mu \mathrm{m}) \text { The injection } \\
\text { volume was } 5 \mu \mathrm{L} \text { with a } \\
\text { flow rate of } 250 \mu \mathrm{L} / \mathrm{min}\end{array}$ & $\begin{array}{l}\text { Mobile phase: acetonitrile and } 5 \mathrm{mM} \\
\text { ammonium acetate containing } 0.1 \% \\
\text { formic acid }(10: 90, \mathrm{v} / \mathrm{v}) \text { provided as an } \\
\text { isocratic elution }\end{array}$ & MS/MS & [49] \\
\hline HPLC & Gland tissue & $\begin{array}{l}\mathrm{C}_{18}(4.6 \mathrm{~mm} \times 150 \mathrm{~mm}, \\
5 \mu \mathrm{m}) \text { The injection volume } \\
\text { was } 50 \mu \mathrm{L} \text { with a flow rate } \\
\text { of } 250 \mu \mathrm{L} / \mathrm{min}\end{array}$ & $\begin{array}{l}\text { Mobile phase: acetonitrile and } 5 \mathrm{mM} \\
\text { ammonium acetate containing } 0.1 \% \\
\text { formic acid }(13 / 87 \mathrm{v} / \mathrm{v}) \text { provided as an } \\
\text { isocratic elution }\end{array}$ & - & {$[30]$} \\
\hline HPLC & $\begin{array}{l}\text { blood and } \\
\text { synovial fluid }\end{array}$ & $\begin{array}{l}\mathrm{C}_{18}(250 \mathrm{~mm} \times 4.6 \mathrm{~mm} \text { i.d., } \\
5 \mu \mathrm{m}), 0.9 \mathrm{~mL} / \mathrm{min} .\end{array}$ & $\begin{array}{l}\text { Linear gradient of acetonitrile in water } \\
\text { with a constant } 0.1 \% \text { trifluoroacetic } \\
\text { acid solution }\end{array}$ & $\begin{array}{l}\text { UV at } \\
268 \mathrm{~nm}\end{array}$ & {$[50]$} \\
\hline LC & Bovine milk & $\mathrm{C}_{18}$ & $\begin{array}{l}\text { Mobile phase: methanol and water } \\
\text { (both with } 0.1 \% \text { of formic acid) }\end{array}$ & ESI-MS/MS & [51] \\
\hline LC & bovine serum & - & - & UV & {$[52]$} \\
\hline HPLC & Plasma & $\begin{array}{l}\mathrm{C}_{18}(250 \mathrm{~mm} \text { by } 4.6 \mathrm{~mm} \text {; } \\
5 \mu \mathrm{m}) .0 .9 \mathrm{~mL} / \mathrm{min}\end{array}$ & $\begin{array}{l}\text { Phenomenex Gemini Mobile phase: } \\
\text { acetonitrile and } 0.1 \% \text { trifluoroacetic } \\
\text { acid in water. }\end{array}$ & $\mathrm{UV}$ at $268 \mathrm{~nm}$ & [53] \\
\hline HPLC & $\begin{array}{l}\text { plasma and } \\
\text { broncho-alveolar } \\
\text { lavage fluid }\end{array}$ & $\mathrm{C}_{18}, 1 \mathrm{~mL} / \mathrm{min}$. & $\begin{array}{l}\text { Mobile phase: } 0.005 \% \text { formic acid and } \\
\text { methanol }\end{array}$ & ESI-MS & {$[54]$} \\
\hline $\begin{array}{l}\text { Absorption } \\
\text { spectrometry UV }\end{array}$ & API & - & $\begin{array}{l}\text { ratio difference, derivative ratio and } \\
\text { mean centering }\end{array}$ & - & {$[55]$} \\
\hline $\begin{array}{l}\text { Electrochemical } \\
\text { method }\end{array}$ & $\begin{array}{l}\text { plasma and } \\
\text { milk }\end{array}$ & - & $\begin{array}{l}\text { Performing Cyclodextrin-Based Ion- } \\
\text { Selective Electrode }\end{array}$ & - & {$[38]$} \\
\hline $\begin{array}{l}\text { Absorption } \\
\text { spectrometry UV }\end{array}$ & API & - & $\begin{array}{l}\text { Zero-, first- and second order } \\
\text { derivative spectrometry }\end{array}$ & $\begin{array}{c}268 \mathrm{~nm} \\
286 \mathrm{~nm}, 311 \mathrm{~nm}\end{array}$ & {$[56]$} \\
\hline $\begin{array}{l}\text { Absorption } \\
\text { spectrometry UV/VIS }\end{array}$ & API & - & $\begin{array}{l}\text { Coupling with ammonium molybdate } \\
\text { in acidic media }\end{array}$ & VIS at $670 \mathrm{~nm}$ & {$[57]$} \\
\hline $\begin{array}{l}\text { Absorption } \\
\text { spectrometry UV/VIS }\end{array}$ & API & - & Differential method & $289 \mathrm{~nm}$ & {$[58]$} \\
\hline
\end{tabular}


Table 2. Microassay method for determination of cefquinome

\begin{tabular}{|c|c|c|}
\hline $\begin{array}{c}\text { Matrices / } \\
\text { Microorganisms } \\
\end{array}$ & Conditions / Methods & References \\
\hline Milk and meat & Utilizing BlaR-CTD to develop a receptor-based ELISA & [59] \\
\hline $\begin{array}{l}\text { Serum and } \\
\text { inflamed tissue }\end{array}$ & PK determination using tissue-cage model & {$[60]$} \\
\hline $\begin{array}{l}\text { Sheep and goat } \\
\text { serum }\end{array}$ & $\begin{array}{l}\text { PKs determination: microbiological assay technique } \\
\text { using Micrococcus luteus (ATCC 9341) as test organism }\end{array}$ & {$[61]$} \\
\hline S. aureus strains & $\begin{array}{c}\text { PK/PD relation: tissue-cage infection model was } \\
\text { established in rabbits }\end{array}$ & [62] \\
\hline $\begin{array}{l}\text { Escherichia coli } \\
\quad \text { isolates }\end{array}$ & $\begin{array}{c}\text { Calculating MICs of cefquinome and applying Monte } \\
\text { Carlo simulation }\end{array}$ & [31] \\
\hline S. aureus strains & $\begin{array}{c}\text { Evaluate PK/PD against an experimental catheter-related } \\
\text { biofilm model due to } \mathrm{S} \text {. aureus }\end{array}$ & [63] \\
\hline Milk & $\begin{array}{c}\text { Investigating methods for the bioremediation of milk } \\
\text { using unpasteurized and UHT milk spiked with } \\
\text { cefquinome as model }\end{array}$ & [64] \\
\hline $\begin{array}{l}\text { Salmonella and } \\
\text { Escherichia coli }\end{array}$ & $\begin{array}{l}\text { Evaluating resistance using minimum inhibitory } \\
\text { concentration determinations and disc diffusion }\end{array}$ & {$[65]$} \\
\hline Food & $\begin{array}{l}\text { A novel microplate assay for the detection and } \\
\text { determination of penicillins and cephalosporins with } \\
\text { intact beta-lactam structure }\end{array}$ & [30] \\
\hline Kidney tissue & $\begin{array}{c}\text { Solid-phase fluorescence immunoassay (SPFIA) } \\
\text { developed for antibiotic residue detection }\end{array}$ & [66] \\
\hline Set of bacteria & $\begin{array}{l}\text { Activity comparison in clinical cultures by determining } \\
\text { MICs }\end{array}$ & [36] \\
\hline
\end{tabular}

The composition and percentage of the mobile phase were varied according to the conditions and to obtain good separation. The responses were recorded using UV, mass spectrophotometry, tandem mass spectrophotometry or electrospray ionization tandem mass spectrophotometry detectors. The columns were mainly $\mathrm{C}_{18}$ with a flow rate ranging between $0.25-1 \mathrm{~mL} / \mathrm{min}$.

Several authors consider methanol as a green solvent compared to acetonitrile, although some authors are more cautious about its use $\mathrm{e}^{24-27}$. Currently, the development of nonaggressive methods to the environment and human health are highly recommended ${ }^{28,29}$. The pharmacokinetics and therapeutic dose of cefquinome were assessed using microbiological methods (Table 2). The techniques used include ELISA, disc diffusion and solid-phase fluorescence immunoassay.

In the literature, reported methods also have described practical methods to be used in the therapeutic drug monitoring. Yu Y et al., ${ }^{30}$ assessed cefquinome dose by pharmacokinetic / pharmacodynamic modeling in mouse model of staphylococcus aureus mastitis. Cefquinome pharmacokinetics, bioavailability and dose assessment was also described by Zhao DH et al., ${ }^{31}$. Lamar J et al, ${ }^{32}$ developed a receptor-based microplate assay for the detection of beta-lactam antibiotics including cefquinome in different food matrices.

Taverne FJ et al., ${ }^{33}$ determined the pharmacokinetic data of cephalosporins by reviewing the available literature for food producing and companion animal species. They assessed the accuracy of allometric scaling in food-producing and companion animals. 
Chin NX et al., ${ }^{34}$ compared the in vitro activity of cefquinome with ceftazidime, cefpirome, and cefepime. Cefquinome was found to inhibit members of the Enterobacteriaceae at less than or equal to 0.5 microgram $/ \mathrm{mL}$ for Escherichia coli, Klebsiella pneumoniae, K. oxytoca, Citrobacter diversus, Salmonella Shigella, Proteus mirabilis, Morganella and Providencia.

Limbert $\mathrm{M}$ et al and Murphy S $\mathrm{P}$ et al., ${ }^{35,36}$ described the in vitro and in vivo antibacterial activity and pharmacokinetics of cefquinome. The in vitro and trends in resistance to antimicrobials were determined by Nedbalcova $\mathrm{K}$ et al. ${ }^{37}$ using a dilution micromethod in a group of Actinobacillus pleuropneumoniae, Pasteurella multocida, Mannheimia haemolytica and Escherichia coli isolates from clinical cases of cattle and swine diseases.

Few methods for the determination of cefquinome in bulk and pharmaceutical formulations by spectrophotometry with absorption in UV and visible region or chromatographic analysis were found in the literature. Those methods determined cefquinome content by either measuring the absorbance values (zero-order, first derivative, second derivative or colorimetric) or the peak areas at specified retention time. The main details are described in Table 1.

Stability study and kinetic monitoring of cefquinome sulfate using cyclodextrin-based ion-selective electrode were developed by Yehia AM, et al. ${ }^{38}$. Shantier SW et al and Dołhań A et al., ${ }^{39,40}$ developed chromatographic and spectrophotometric methods for the analysis and stability studies of cefquinome sulphate in bulk and pharmaceutical dosage forms.

\section{Conclusion}

Infections are the second leading reason for mortality worldwide which justifies the need to study the effectiveness of and improve the present antimicrobials/ antibiotics available for the animals or human use.

This article summarized a brief review on the characteristics and reported methods for the analysis of cefquinome in different matrices (plasma, urine, serum and bulk and dosage forms).

Despite the advantages of some of those techniques, relevant points to consider are the complexity, analyte amount and sample treatment especially with toxic solvents. Currently, the development of non-aggressive methods to the environment and human health are highly recommended.

In pharmaceutical analysis, preference is always directed towards development of simple, feasible and cost effective methods. Development of such methods will be of great impact specifically for during and in-process control and for the routine quality control of drugs.

\section{Competing interests}

The author declares no conflict of interest

\section{Funding}

The current work was self sponsored.

\section{References}

1. The ABC's of Antibiotics, Retrieved, 11 October 2019; http://professionals.site.apic.org/files/2013/10/AntibioticInfographic14FINAL.pdf 
2. Factsheet for experts, European Centre for Disease Prevention and Control. Retrieved 21 December 2014.

3. Calderon C B and Sabundayo B P, Antimicrobial Classifications: Drugs for Bugs. In Schwalbe R, Steele-Moore L and Goodwin A C, Antimicrobial Susceptibility Testing Protocols. CRC Press. Taylor and Frances group, 1990.

4. Scott H H, Brudvig J, James D, Mirceta J, Polvinski M, Mattheus N and Griffith R, Public Health Report, 2008, 123(3), 343-351; DOI:10.1177/003335490812300314

5. Singer R S, Louis A, Cox Jr, James S D, Scott, H H, Ian P and Gay Y M, Prev Vet Med., 2007, 79, 186-203; DOI:10.1016/j.prevetmed.2006.12.003

6. Guimarães D O, Momesso L S and Pupo M T, Química Nova., 2010, 33(3), 667-679.

7. Brooks B D and Brooks A E, Adv Drug Del Rev., 2014, 78, 14-27; DOI:10.1016/j.addr.2014.10.027

8. Oldifield E and Feng X, Trends Pharmacol Sci., 2014, 35(12), 664-674; DOI:10.1016/j.tips.2014.10.007

9. Harle D G, Baldo B A and Wells J V, Mol Immunal., 1988, 25(12), 1347-1354; DOI:10.1016/0161-5890(88)90050-8

10. La Roca M F, Sobrinho J L S, Nunes L C C and Neto P J R, Brasilian J Pharmacy, 2007, 88, 177-180.

11. Climeni B S O, Dellalibera F L, Monteiro M V, Bazan C T and Pereira D M, Revista Científica Eletrônica de Medicina Veterinária, 2009, 12, 1-8.

12. Katzung B G, Masters S B and Trevor A J, Basic Pharmacology and Clinical. McGraw Hill, Inter American of Brazil: São Paulo, Brazil, 2009.

13. https://www.drugs.com

14. https://pubchem.ncbi.nlm.nih.gov/compound/5464355

15. Brown Raymond F, Kinnick Michael D, Morin John M, Vasileff Robert T, Counter Fred T, Davidson Edward O, Ensminger Paul W, Eudaly Judith A and Kasher Jeffrey S, J Med Chem., 1990, 33(8), 2114-2121; DOI:10.1021/jm00170a011

16. https://ncit.nci.nih.gov/ncitbrowser/ConceptReport.jsp?dictionary=NCI_Thesaurus\& ns $=$ NCI_Thesaurus\&code $=C 79564$

17. Risk estimation for cefquinome to evaluate potential microbiological effects on bacteria of human health concern, 2006. [Cited June 2012]. Available from: www.fda.gov.

18. Mandell G L, Bennett J E and Dolin R, Anti-infective therapy. Volume I Part I Section E, In: Mandell, Douglas and Bennett's Principals and Practice of Infectious Diseases, $5^{\text {th }}$ Ed., Churchill Livingstsone, 2000.

19. Rick Weiss, "FDA Rules Override Warnings About Drug", The Washington Post, March 4, 2007, sec. A01

20. Lee D C and Webb M L, Pharmaceutical Analysis; Blackwell Publishing Ltd: Oxford, 2003.

21. Hanna-Brown M, Anal Methods, 2012, 4(6), 1484; DOI:10.1039/C2AY90024F

22. Bonfilio R, Cazedey E C L, Araújo M B de and Salgado H R N, Crit Rev Anal Chem., 2012, 42(1), 87-100

23. Siddiqui M R, AlOthman Z A and Rahman N A, Arab J Chem., 2017, 10(1), S1409S1421; DOI:10.1016/j.arabjc.2013.04.016

24. Capello C, Fischer U and Hungerbühler K, Green Chem., 2007, 9, 927-934; DOI:10.1039/B617536H

25. Byrne F P, Jin S, Paggiola G, Petchey T H M, Clark J H, Farmer T J, Hunt A J, McElroy C R, Sherwood J, Sustain Chem Process., 2016, 4(7), 1-24; DOI:10.1186/s40508-016-0051-z 
26. Curzons A D Constable D C and Cunningham V L, Clean Prod Process, 1999, 1(2), 82-90; DOI:10.1007/s100980050014

27. Henderson R K, Jiménez-González C, Constable D J C, Alston S R, Inglis G G A, Fisher G, Sherwood J, Binks S P and Curzons A D, Green Chem., 2011, 4, 854-862; DOI:10.1039/C0GC00918K

28. Alfonsi K, Colberg J, Dunn P J, Fevig T, Jennings S, Johnson T A, Kleine H P, Knight C, Nagy M A, Perry D A, et al. Green Chem., 2008, 10(1), 31-36; DOI:10.1039/B711717E

29. Płotka J, Tobiszewski M, Sulej A M, Kupska M, Górecki T and Namieśnik J, J Chromatogr A, 2013, 13, 1-20; DOI:10.1016/j.chroma.2013.07.099

30. Yu Y, Zhou Y F, Li X, Chen M R, Qiao G L, Sun J, Liao X P and Liu Y H, Front Microbiol., 2016, 7(7), 1595; DOI:10.3389/fmicb.2016.01595

31. Zhao D H, Wang X F, Wang Q and Li L D, BMC Vet Res., 2017, 13(1), 226; DOI:10.1186/s12917-017-1148-7

32. Lamar J and Petz M, Anal Chim Acta, 2007, 586(1-2), 296-303; DOI:10.1016/j.aca.2006.09.032

33. Taverne F J, van Geijlswijk I M, Heederik D J, Wagenaar J A and Mouton J W, BMC Vet Res., 2016, 12(1), 185; DOI:10.1186/s12917-016-0817-2

34. Chin N X, Gu J W, Fang W and Neu H C, Diagn Microbiol Infect Dis., 1992, 15(4), 331-337; DOI:10.1016/0732-8893(92)90019-P

35. Limbert M, Isert D, Klesel N, Markus A, Seeger K, Seibert G and Schrinner E, Antimicrob Agents Chemother, 1991, 35(1), 14-19; DOI:0.1128/aac.35.1.14

36. Murphy S P, Erwin M E and Jones R N, Diagn Microbiol Infect Dis., 1994, 20(1), 4955; DOI:10.1016/0732-8893(94)90019-1

37. Nedbalcova K, Nechvatalova K, Pokludova L, Bures J, Kucerova Z, Koutecka L and Hera A, Vet Microbiol., 2014, 171(3-4), 328-336; DOI:10.1016/j.vetmic.2014.02.004

38. Yehia A M, Arafa R M, Abbas S S and Amer S M, J AOAC Int., 2016, 99(1), 73-81; DOI:10.5740/jaoacint.15-0185

39. Shantier S W, Gadkariem E A, Adam M O and Mohamed M A, Int J Biomed Sci., 2013, 9(3), 162-167.

40. Dołhań A, Jelilńska A and Manuszewska M, Acta Pol Pharm., 2014, 71(2), 249-254.

41. Hou X L, Wu Y L, Lv Y, Xu X Q, Zhao J and Yang T, J Chromatogr B Analyt Technol Biomed Life Sci., 2013, 15(931), 6-11; DOI:10.1016/j.jchromb.2013.05.006

42. Dinakaran V, Dumka V K, Ranjan B, Balaje R and Sidhu P K, Trop Anim Health Prod., 2013, 45(7), 1509-1512; DOI:10.1007/s11250-013-0390-7

43. Xie W, Zhang X, Wang $\mathrm{T}$ and Du S, British Poult Sci., 2013, 54(1), 81-86; DOI:10.1080/00071668.2013.764399

44. Quesada-Molina C, García-Campaña A M and del Olmo-Iruela M, Talanta, 2013, 15(115), 943-949; DOI:10.1016/j.talanta.2013.07.008

45. Wang J, Shan Q, Ding H, Liang C, Zeng Z, Antimicrob Agents Chemother, 2014, 58(6), 3008-3012; DOI:10.1128/AAC.01666-13

46. Di Rocco M, Moloney M, O'Beirne T, Earley S, Berendsen B, Furey A and Danaher M, J Chromatogr A, 2017, 1500, 121-135; DOI:10.1016/j.chroma.2017.04.022

47. Chiesa L M, Nobile M, Panseri S and Arioli F, Food Chem., 2017, 15(235), 111-118; DOI:10.1016/j.foodchem.2017.04.184

48. Baeza A N, Urraca J L, Chamorro R, Orellana G, Castellari M and Moreno-Bondi M C, J Chromatogr A, 2016, 1474, 121-129; DOI:10.1016/j.chroma.2016.10.069 
49. Shan, Q and Wang J, J Vet Pharmacol Ther., 2017, 40(4), 392-397; DOI:10.1111/jvp. 12365

50. Uney K, Altan F, Altan S, Erol H, Arican M and Elmas M, $J$ Vet Pharmacol Ther., 2017, 40(3), 239-247; DOI:10.1111/jvp.12362

51. Jank L, Martins M T, Arsand J B, Hoff R B, Barreto F and Pizzolato T M, Part A Chem Anal Control Expo Risk Assess., 2015, 32(12), 1992-2001; DOI:10.1080/19440049.2015.1099745

52. Ahmad I, Hao H, Huang L, Sanders P, Wang X, Chen D, Tao Y, Xie S, Xiuhua K, Li J, Dan W and Yuan Z, Front Microbiol., 2015, 17(6), 588; DOI: $10.3389 /$ fmicb.2015.00588

53. Uney K, Altan F and Elmas M, Antimicrob Agents Chemother., 2011, 55(2), 854-859; DOI:10.1128/AAC.01126-10

54. Maes A, Meyns T, Sustronck B, Maes D, De Backer P and Croubels S, J Mass Spectrom., 2007, 42(5), 657-663; DOI:10.1002/jms.1199

55. Yehia A M, Arafa R M, Abbas S S and Amer S M, Spectrochim Acta A: Mol Biomol Spectrosc., 2016, 153, 231-240; DOI:10.1016/j.saa.2015.08.037

56. Shantier S W and Gadkariem E A, Elixir Pharmacy, 2013, 59, 15471-15473.

57. Shantier S W and Gadkariem E A, American J Appl Sci., 2014, 11(2), 202-206; DOI:10.3844/ajassp.2014.202.206

58. Shantier S W and Gadkariem E A, British J Pharma Res., 2014, 4(5), 617-625.

59. Peng J, Cheng G, Huang L, Wang Y, Hao H, Peng D, Liu Z and Yuan Z, Anal Bioanal Chem., 2013, 405(27), 8925-8933; DOI:10.1007/s00216-013-7311-5

60. Shan Q, Yang F, Wang J, Ding H, He L and Zeng Z, J Vet Pharmacol Ther., 2014, 37(2), 178-185; DOI:10.1111/jvp.12076

61. El-Hewaity M, Abd El Latif A, Soliman A and Aboubakr M, J Vet Med., 2014, 2014, 949642; DOI:10.1155/2014/949642

62. Xiong M, Wu X, Ye X, Zhang L, Zeng S, Huang Z, Wu Y, Sun J and Ding H, Front Microbiol., 2016, 7(7), 874; DOI:10.3389/fmicb.2016.00874

63. Zhou Y F, Shi W, Yu Y, Tao M T, Xiong Y Q, Sun J and Liu Y H, Front Microbiol., 2016, 7(6), 1513; DOI:10.3389/fmicb.2015.01513

64. Horton R A, Randall L P, Bailey-Horne V, Heinrich K, Sharman M, Brunton L A, La Ragione R M and Jones J R, J Appl Microbiol., 2015, 118(4), 901-910; DOI:10.1111/jam.12765

65. Aarestrup F M, Hasman H, Veldman K and Mevius D, Microb Drug Resist., 2010, 16(4), 253-261; DOI:10.1089/mdr.2010.0036

66. Okerman L, De Wasch K, Van Hoof J and Smedts W, J AOAC Int., 2003, 86(2), 236-240. 